F. Reprod. Fert. (1970) 21, 203-205

\title{
DNA ACTIVITY IN THE ENDOMETRIAL STROMA OF THE CYCLING RAT AS MEASURED BY FEULGEN STAINING AND BY $\left[{ }^{3} \mathrm{H}\right]$ THYMIDINE INCORPORATION
}

\author{
F. LEROY AND P. GALAND \\ Laboratory of Experimental Gynaecology (Saint-Pierre Hospital), Brussels, and \\ Laboratory of Nuclear Medicine, Free University of Brussels
}

(Received 11th September 1969)

By using cytophotometry, Fautrez (1966) and his colleagues have shown in a variety of hormonal receptors (i.e. thyroid, adrenals, ovary and vagina) that specific stimulation leads to an increase of Feulgen-measured DNA within the nuclei of target cells. According to these authors, this phenomenon is not necessarily related to an enhanced mitotic rate but would witness to a hormonedependent metabolic activity.

As similar data were obtained in the uterus of spayed mice (Leroy, Manavian \& Hubinont, 1967) and rats (Leroy \& Manavian, 1969), the present work was undertaken in order to verify if this concept is applicable to the endometrial stroma during the oestrous cycle.

The oestrous cycles of groups of four animals (Wistar strain) were followed by daily vaginal smears and animals were killed around mid-day at various moments of the cycle (i.e. pro-oestrus, early and late oestrus and early and late di-oestrus). Sections of the uteri were homogeneously Feulgen-stained. The relative Feulgen-DNA content was determined with the Lison histophotometer (Lison, 1950) in about 100 stromal nuclei per uterus. The results obtained in groups of animals were pooled and statistically analysed according to the large samples method described by Snedecor (1956). As the observed values showed a log-normal distribution, the mean $(\log x)$ and standard error were calculated on a logarithmic basis. The significance of differences between adjacent groups was estimated by Student's ' $t$ ' test. These results are shown in Table 1.

Another series of animals was selected according to the same criteria. They received an intraperitoneal pulse injection of $\left[{ }^{3} \mathrm{H}\right]$ thymidine $(10 \mu \mathrm{c} / \mathrm{g}$ body weight) $15 \mathrm{~min}$ before being killed. The uteri were processed for autoradiography. Labelling indices were counted on at least 3000 stromal cells (leucocytes were not taken into account). Numerical results and significance of differences between mean values corresponding to successive experimental groups are given in Table 2.

It was observed that the mean nuclear DNA content, as measured by Feulgen staining, rises sharply $(18 \%)$ between early and late oestrus. During di-oestrus, this parameter progressively returns to the low values observed in pro-oestrus and early oestrus. 
From the end of di-oestrus up to the first day of oestrus, $\left[{ }^{3} \mathrm{H}\right]$ thymidine labelling indices were found to be relatively high and did not vary significantly, although there is some indication that the rise from pro-oestrus to oestrus could be meaningful $(P=0 \cdot 1)$. From the end of oestrus to the first half of di-oestrus, a significant decrease takes place in the number of nuclei which have taken up $\left[{ }^{3} \mathrm{H}\right]$ thymidine.

The comparison of results obtained with Feulgen cytophotometry and autoradiography indicates that the peak of Feulgen-measured DNA observed at

TABLE 1

MEAN RELATIVE FEULGEN-DNA CONTENT OF ENDOMETRIAL STROMAL NUGLEI IN THE GYGLING RAT

\begin{tabular}{|c|c|c|c|c|}
\hline Stages & $\begin{array}{c}\text { No. of } \\
\text { rats }\end{array}$ & $\begin{array}{l}\text { No. of } \\
\text { nuclei }\end{array}$ & $\log \bar{x} \pm S . E$. & $\mathbf{P}$ \\
\hline $\begin{array}{l}\text { Pro-oestrus } \\
\text { Oestrus (first half) } \\
\text { Oestrus (second half) } \\
\text { Di-oestrus (first half) } \\
\text { Di-oestrus (second half) }\end{array}$ & $\begin{array}{l}4 \\
4 \\
4 \\
4 \\
4\end{array}$ & $\begin{array}{l}400 \\
394 \\
397 \\
389 \\
386\end{array}$ & $\begin{array}{l}2 \cdot 70030 \pm 0.003 \\
2 \cdot 69663 \pm 0.005 \\
2 \cdot 76378 \pm 0.004 \\
2 \cdot 73094 \pm 0.004 \\
2 \cdot 72146 \pm 0.004\end{array}$ & $\begin{aligned} & \text { N.S. } \\
&<0.001 \\
&<0.001 \\
& \text { N.S. } \\
&<0.001\end{aligned}$ \\
\hline
\end{tabular}

N.S. = not significant.

TABLE 2

$\left[{ }^{3} \mathrm{H}\right]$ THYMIDINE LABELLING INDEX IN THE ENDOMETRLAL STROMA OF THE RAT DURING THE OESTROUS GYGLE

\begin{tabular}{l|c|c|c}
\hline \multicolumn{1}{c|}{ Stages } & $\begin{array}{c}\text { No. of } \\
\text { rats }\end{array}$ & $\begin{array}{c}\text { Labelling index } / 1000^{*} \\
\pm S . E .\end{array}$ & $\mathrm{P}$ \\
\hline Pro-oestrus & 3 & $4.4 \pm 0.8$ & N.S. \\
Oestrus (first half) & 3 & $7.8 \pm 1.4$ & 0.05 to 0.02 \\
Oestrus (second half) & 3 & $2.4 \pm 1.2$ & N.S. \\
Di-oestrus (first half) & 4 & $1.35 \pm 0.2$ & 0.01 to 0.001 \\
Di-oestrus (second half) & 4 & $8.4 \pm 1.9$ & N.S. \\
\hline
\end{tabular}

* Number of labelled endometrial stroma cells per thousand.

N.S. = not significant.

the end of oestrus cannot be accounted for by an accelerated proliferation rate since there is no concomitant increase in the proportion of DNA-synthesizing cells as measured by the uptake of labelled thymidine. An alternative hypothesis would be that, after having passed through the $S$ phase (DNA synthesis) of the mitotic cycle, the endometrial stromal cells remain dormant in the $G_{2}$ (premitotic) phase and thus contain a tetraploid amount of DNA, as is the case in certain other tissues (Gelfant, 1963). Such an explanation seems to be precluded by the finding that, in every experimental group, cytophotometrical values were log-normally distributed, without sufficient numbers of tetraploid $\left(G_{2}\right)$ nuclei (never more than 1 to $3 \%$ ) to justify the observed shift of mean Feulgen-DNA from the 1st to the 2 nd day of oestrus.

Thus, it is clear that during the oestrous cycle in the rat the action of ovarian hormones results in two different time-dependent effects on endometrial 
stromal nuclei, i.e. increased thymidine incorporation and intensification of Feulgen staining.

In connexion with regulation of genetic transcription by sex steroids, it was recently shown in the normal rat that chromatin isolated from the uterus in oestrus exhibits an increased DNA template capacity, a higher ratio of total proteins to DNA and a smaller proportion of histones than in di-oestrus (Hamilton, 1968). On the other hand, the efficacy of hydrolysis for Feulgen reaction depends on the amount and nature of the nuclear proteins (Walker \& Richards, 1959; Böhm \& Sandritter, 1966). As a possible working hypothesis, sex steroids might be considered capable of increasing the amount of DNA available for Feulgen hydrolysis by modifying in some way the nucleo-proteinDNA bonds and Feulgen staining intensity might (at least partially) reflect genetic de-repression induced by hormones.

This work was supported by grants from the Belgian National Council for Scientific Research and from the Fund for Medical Scientific Research.

\section{REFERENGES}

BöHм, N. \& SANDRITtER, W. (1966) Feulgen hydrolysis of normal cells and mouse ascites tumor cells. 7. Cell Biol. 28, 1.

Fautrez, J. (1966) Le dynamisme des acides nuckeiques. Gauthier-Villars, Paris.

Gelfant, S. (1963) A new theory on the mechanism of cell division. In: Cell growth and cell division, p. 229. Ed. R. J. C. Harris. Academic Press, New York.

Hamilton, T. H. (1968) Control by estrogen of genetic transcription and translation. Science, N.Y. 161, 649.

Leroy, F. \& Manavian, D. (1969) Etude histophotométrique de l'endomètre. III. Evolution de l'intensité de la réaction de Feulgen dans les noyaux du stroma après injection unique de stéroìdes sexuels. Revue fr. Etud. clin. biol. 14, 59.

Leroy, F., Manavian, D. \& Hubinont, P. O. (1967) Nuclear DNA estimations in the Hooker and Forbes test with sex hormones. F. Endocr. 39, 227.

Lison, L. (1950) Etude et réalisation d'un photomètre à l'usage histologique. Acta anat. 10, 333.

SNedecor, G. W. (1956) Statistical methods. The Iowa State University Press, Ames.

WAlKer, P. M. B. \& Richards, B. M. (1959) Quantitative microscopical techniques for single cells. In: The Cell, p. 816. Eds. J. Brachet and A. Mirsky. Academic Press, New York. 